\title{
Prof. Franca Melfi: robot is the future
}

Received: 31 October 2018; Accepted: 20 November 2018; Published: 22 November 2018.

doi: 10.21037 /jovs.2018.11.03

View this article at: http://dx.doi.org/10.21037/jovs.2018.11.03

\section{Expert introduction}

Prof. Franca Melfi (Figure 1) presently is Professor of Thoracic Surgery at Medical School of the University of Pisa and Chair of Robotic Multidisciplinary Centre for Surgery-Thoracic MIS and Robotic surgery at the University Hospital of Pisa.

She has been mainly focusing on lung cancer (specifically, sentinel lymph-node mapping in lung cancer), lung cancer in women, tracheal surgery and robotic surgery.

Presently, Prof. Melfi is carrying out research on the application of high-technology in surgery (robotic surgery), focusing on robotic surgery for the standardization of procedures and clinical application in the field of thoracic surgery.

In 2005 along with a group of professional women she founded the ONG Association AIDAcp (Women Association against Lung Cancer). The intent of this association was to share problems relative to neoplastic lung pathology in women, to disseminate information, mentor young trainees, transfer data within the context of programs and social initiatives of pragmatic intervention.

Working within this association, as vice-president and thoracic surgeon, she has been carrying on the research program regarding epidermal growth factor receptor (EGFR) and K-Ras mutations in adenocarcinoma of the lung, in cooperation with the Oncological Institute of Tuscany (ITT) and other European Institutions.

\section{Editor's notes}

The $9^{\text {th }}$ International Thymic Malignancy Interest Group Annual Meeting (ITMIG 2018 Annual Meeting) was held successfully in Seoul, Korea from October $25^{\text {th }}$ to October $27^{\text {th }}, 2018$. As the premier multi-disciplinary international organization focused on the thymic gland and tumors, the ITMIG 2018 Annual meeting, gathering together numerous clinicians, researchers, and scientists from all over the world discussing and exploring the advances in the management of thymic malignancies, provided an ideal forum to exchange the knowledge of latest scientific advances, to share ideas

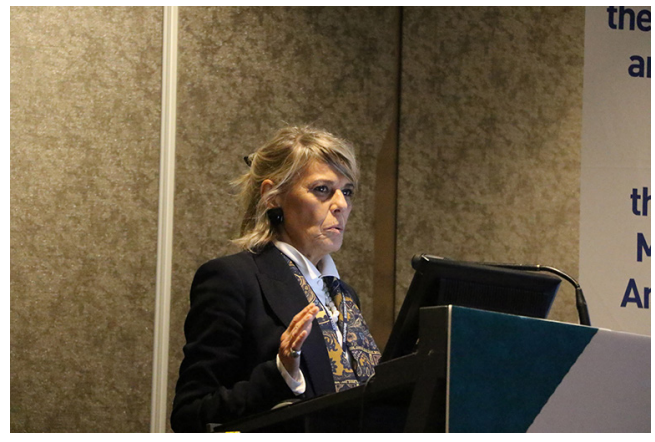

Figure 1 Prof. Franca Melfi.

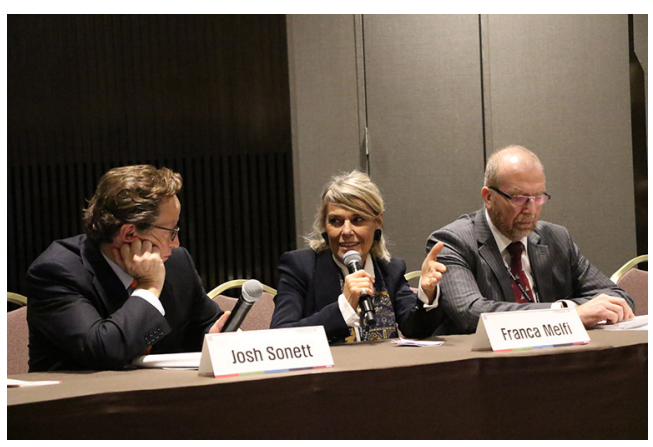

Figure 2 Prof. Franca Melfi in the meeting.

in the new development of clinical management, and to provide unique networking opportunities.

During the meeting, Prof. Franca Melfi (Figure 2) from the University of Pisa has presented an interesting topic about "Initiating a MIS TET program: case selection, simulation, proctorship", earning quite a lot attention from the audience. Taking this opportunity, the editorial office of Fournal of Visualized Surgery is honored to invite Prof. Franca Melfi for an interview, sharing with us some takehome messages of the speech as well as her passion and perspective about robotic surgery and its future (Figure 3).

At the beginning of the interview, Prof. Melfi pointed out the fact that though many young surgeons and residents nowadays are enthusiastic of new technology, they don't know very well the basic rules/principle of surgery. As this 


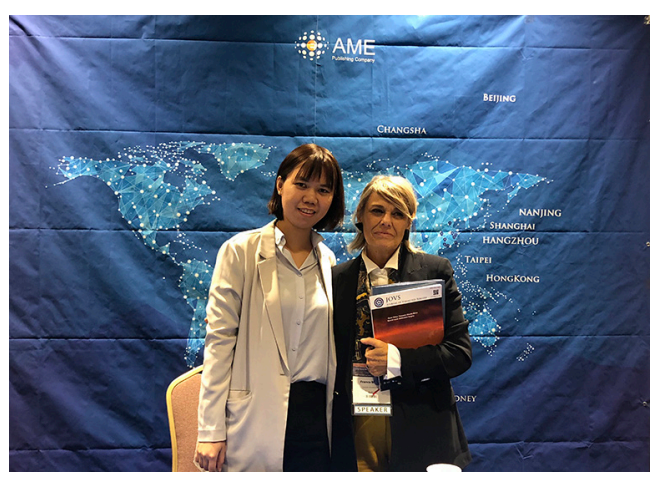

Figure 3 Picture with Prof. Franca Melfi.

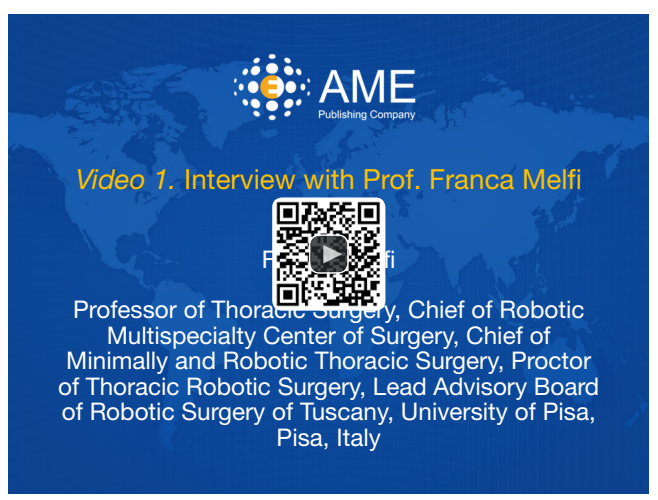

Figure 4 Interview with Prof. Franca Melfi (1).

Available online: http://www.asvide.com/article/view/28427

could really cause big mistake, Prof. Melfi emphasized it's important to teach young surgeons to respect and understand the principle of surgery before starting with a new technology or a new technique.

Meanwhile, Prof. Melfi also mentioned about the importance of mastering the use of instrument one has to use for a surgery, specifically for robotic surgery. Surgeons need to understand how the platform and how the system works. Otherwise, it'll be really a challenge and even causes dangerous situation for patients. Regarding this aspect, Prof. Melfi suggested to have a good proctor and take good use of books for learning and practise.

As chief of Global Robotic surgical training center and expert in the robotic surgery, Prof. Melfi believed that Robot will be the future and will take significant role in the medical world. Besides, Prof. Melfi also shared her precious experience when first did the robotic surgery: from a challenge to become the nice experience, from discussing with the team, practicing a lot together to finally obtaining good result, all of which were precious memory and significant for her as a robotic surgeon.

"If using three words to describe the Robotic surgery, what would you say?" Prof. Melfi told her answers excitedly: "Precision, Vision, and Maneuverability!" For more details, please click the video (Figure 4).

\section{Interview questions}

(I) Today you've presented the topic about "Initiating a MIS TET program: case selection, simulation, proctorship". Here would you share some take-home messages of the speech to our readers?

(II) What would be the common challenge for it?

(III) What would be your suggestion to overcome this challenge?

(IV) How do you think about the future of surgery?

(V) As an expert in the robotic surgery, what would be your perspective about the role of robot in the future medicine?

(VI) Would you like to share with us your early experience when you first did the robotic surgery?

(VII) If to choose three words to describe the Robotic Surgery, which words will you choose?

\section{Acknowledgments}

Funding: None.

\section{Footnote}

Provenance and Peer Review: This article was commissioned by the editorial office, fournal of Visualized Surgery for the series "Meet the Professor". The article did not undergo external peer review.

Conflicts of Interest: The author has completed the ICMJE uniform disclosure form (available at: http://dx.doi. org/10.21037/jovs.2018.11.03). The series "Meet the Professor" was commissioned by the editorial office without any funding or sponsorship. The author reports that she is a full-time employee of AME Publishing Company (publisher of the journal). The author has no other conflicts of interest to declare.

Ethical Statement: The author is accountable for all aspects of the work in ensuring that questions related 
to the accuracy or integrity of any part of the work are appropriately investigated and resolved.

Open Access Statement: This is an Open Access article distributed in accordance with the Creative Commons Attribution-NonCommercial-NoDerivs 4.0 International License (CC BY-NC-ND 4.0), which permits the noncommercial replication and distribution of the article with the strict proviso that no changes or edits are made and the original work is properly cited (including links to both the

doi: 10.21037/jovs.2018.11.03

Cite this article as: Skylar Gao. Prof. Franca Melfi: robot is the future. J Vis Surg 2018;4:239. formal publication through the relevant DOI and the license). See: https://creativecommons.org/licenses/by-nc-nd/4.0/.

\section{References}

1. Gao S. Interview with Prof. Franca Melfi. Asvide 2018;5:862. Available online: http://www.asvide.com/ article/view/28427

(Science Editor: Skylar Gao, JOVS, jovs@amepc.org) 